MediaTor, Vol 12 (1), Juni 2019, 81-89

\title{
Komunikasi Perempuan dalam Keluarga Berpoligami di Madura
}

\author{
${ }^{1}$ Nikmah Suryandari, ${ }^{2}$ Roos Yuliastina \\ ${ }^{1}$ Prodi Ilmu Komunikasi Fakultas Ilmu Sosial dan Ilmu Budaya, Universitas Trunojoyo, Madura \\ ${ }^{2}$ FISIP Universitas Wiraraja Sumenep \\ E-mail: 1nikmahsuryandari@gmail.com, ${ }^{2}$ yuliastina07@gmail.com
}

\begin{abstract}
Abstrak: Fenomena poligami menjadi polemik dalam negara timur, seperti Indonesia. Sebagai negara mayoritas muslim Indonesia mengenal dua sistem dalam berkeluarga, yaitu sistem monogami dan poligami. Pernikahan di wilayah Bangkalan Madura tidak jauh berbeda dengan sistem pernikahan tradisional di daerah lain. Praktek poligami pada mulanya hanya dilakukan oleh laki-laki Madura yang memiliki jabatan atau memiliki materi lebih, seperti tokoh agama, pejabat, atau seorang blater yang berpengaruh dalam lingkungan masyarakat. Namun praktik poligami yang terjadi belakangan ini dilakukan pula oleh laki-laki Madura yang tidak berkecukupan secara materi. Dengan kondisi diatas, fenomena praktek poligami di Bangkalan Madura dapat diibaratkan seperti fenomena gunung es. Masalah dalam penelitian ini adalah bagaimana komunikasi perempuan dalam keluarga berpoligami di Bangkalan Madura? Penelitian ini menggunakan paradigma konstruktivis dengan jenis penelitian kualitatif deskriptif. Pengumpulan data ini menggunakan wawancara mendalam (depth interviews), observasi. Informan dalam penelitian ini adalah para perempuan dalam perkawinan poligami, baik istri pertama maupun istri kedua. Informan pendukungnya adalah suami dalam keluarga berpoligami serta kerabat perempuan yang dipoligami. Hasil penelitian ini menunjukkan bahwa dalam komunikasi perempuan dalam keluarga berpoligami di Bangkalan, menggunakan pesan kontradiktif dalam menyampaikan pesan terutama kepada madu nya. Komunikasi perempuan dalam keluarga berpoligami juga melibatkan komunikasi verbal dan non verbal diantara pelakunya. Komunikasi perempuan dalam keluarga berpoligami juga berpotensi menimbulkan konflik.
\end{abstract}

Kata kunci : komunikasi, perempuan, Madura, keluarga berpoligami

\begin{abstract}
The phenomenon of polygamy has become a polemic in eastern countries, such as Indonesia. As a Muslim country, Indonesia recognizes two systems in families, namely the system of monogamy and polygamy Marriage in Madura is not much different from the traditional marriage system in other regions. The practice of polygamy was initially only carried out by Madurese men who had positions or had more material, such as religious leaders, officials, or blater. However, this practice of polygamy is currently being carried out by Madurese men who are not material enough. Based on this, the practice of polygamy from Madura can be likened to an iceberg phenomenon. The problem in this research is how is the communication of women in polygamous families in Madura? This study uses a constructivist paradigm with descriptive qualitative research. This data collection uses in-depth interviews, observations. This study uses a constructivist paradigm with descriptive qualitative research. This data collection uses depth interviews, observations. Informants in this study were women in polygamous marriages, both first and second wives. The supporting informants were husbands in polygamous families and polygamous female family. The results of this study indicate that in the communication of women in polygamous families in Bangkalan, using contradictory messages in conveying messages, especially first wives to second wives. Communication of women in polygamous families also involves verbal and nonverbal communication among the participants. Communication of women in polygamous families also has the potential to cause conflict.
\end{abstract}

Keywords : communication,women, Madura, polygamous families 


\section{PENDAHULUAN}

Selama ini ada asumsi yang beredar bahwa poligami terjadi salah satunya karena jumlah perempuan lebih banyak dari laki-laki. Ternyata hal ini tidak sepenuhnya benar. Data terbaru hasil sensus penduduk 2010 yang dilansir BPS menyebutkan, jumlah penduduk Indonesia adalah 237.641.326 (237,6 juta) jiwa, terdiri dari 119.630.913 (119,6 juta) laki-laki dan 118.010.413 (118 juta) perempuan. Artinya, jumlah penduduk laki-laki justru lebih banyak dengan rasio 101:100. Dibandingkan data sensus tahun 2000, rasio jenis kelamin laki-laki mengalami peningkatan satu poin dari sebelumnya 100:100. Rasio jenis kelamin pada hasil sensus sebelumsebelumnya, sejak tahun 1971, juga tidak jauh beda, yakni di kisaran 97:100 sampai 99:100. (http://bermenschool.wordpress. com).

Data ini diperkuat oleh Hujaemah T Yanggo, yang mengutip data Biro Pusat Statistik (BPS) dan Badan Koordinasi Keluarga Berencana Nasional (BKKBN) tentang perbandingan jumlah laki-laki dan perempuan. Saat ini, kata Hujaemah, jumlah laki-laki sebanyak 50,2 persen, sebanding dengan jumlah perempuan sebesar 49,2 persen. (kemenag.go.id/ berita/78883, 2007).

Sampai saat ini sikap masyarakat Indonesia terhadap pernikahan poligami masih kontroversi, bagi sebagian masyarakat pro poligami hal tersebut dianggap wajar, ketika seorang laki-laki dewasa merasa "cukup" untuk memadu istrinya, dengan alasan bahwa aturan agama (Islam) dan Undang-Undang pemerintah melegalkan praktek poligami.

Seperti yang terjadi di Madura, garis budaya yang dekat nuansa keislamannya secara sadar maupun tidak memang mendukung praktek poligami menjadi suatu yang tidak melanggar untuk dilakukan. Sekilas tentang watak orang Madura menjadi pandangan khalayak, dikutip dari Mien Rifa'i (Rifa'i, 2007): 'orang Madura memiliki sifat keras, cenderung temperamental, pemberani, memiliki etos kerja yang tinggi, dan memiliki ketaatan agama yang tinggi pula pada tiap kehidupannya"

Fenomena poligami menjadi polemik dalam negara timur, seperti Indonesia. Sebagai negara mayoritas muslim Indonesia mengenal dua sistem dalamberkeluarga, yaitu sistem monogami dan poligami. Idealnya sistem pernikahan masyarakat Indonesia adalah pernikahan monogami seperti yang diatur dalam UUP No.1 Tahun 1974 Pasal 3 ayat (1), menyatakan : Pada dasarnya dalam suatu perkawinan seorang pria hanya boleh mempunyai seorang istri. Seorang wanita hanya boleh mempunyai seorang suami. Berbeda dengan pernikahan poligami, sebuah pernikahan yang dilakukan oleh seorang suami dengan ostri lebih dari satu. Pernikahan poligami juga telah dilegalkan sesuai UUP No.1 Tahun 1974 Pasal 3 ayat (2) menyatakan : Pengadilan dapat memberi izin kepada seorang suami untuk beristri lebih dari seorang apabila dikehendaki oleh pihak-pihak yang bersangkutan (Martadikusumah,2010:11)

Pernikahan di Madura tidak jauh berbeda dengan sistem pernikahan tradisional di daerah lain. Pernikahan dini masih terjadi dalam lingkungan masyarakat tradisionalnya. Menurut penuturan salah seorang informan penelitian, ketika seorang perempuan sudah mendapat haid, maka perempuan tersebut dikatakan siap untuk berumah tangga, meskipun usianya masih belia (15-16 tahun). Hal ini bertujuan untuk menjaga kehormatan dan menjauhkan perempuan Madura dan keluarganya dari fitnah. Fakta seperti ini diperkuat oleh pernyataan Menissi (Mernissi, 1997) bahwa "konsep tentang wanita remaja, yang telah mengalami menstruasi dan masih tetap melajang adalah sesuatu yang asing bagi seluruh sistem keluarga 
muslim, sehingga hal ini merupakan sesuatu yang tidak terbayangkan atau selalu dikaitkan dengan fitnah (kekacauan sosial)"

Nilai-nilai kehormatan, harga diri bagi laki-laki dan kepatuhan seorang perempuan (istri) pada suami dan orang tuanya, serta perkawinan berlandaskan agama menjadi hal yang ikut mengkonstruksi norma sosial masyarakatnya. Dalam tulisan (Rahmawati, 2007) nilai-nilai keperawanan, kepantasan pergaulan lelaki dan perempuan, perkawinan, larangan terhadap seks diluar nikah semuanya memperoleh aturan yang tegas dan ditransformasikan dari generasi ke genarasi secara adat dan norma-norma sosial budaya, dengan landasan agama dalam kehidupan mereka seperti di Madura.

Masih menurut (Rahmawati, 2007) dalam masyarakat Madura tradisional, menerima anak gadis mereka untuk dimadu adalah pilihan "lebih baik" daripada anak mereka hidup melajang atau rumah tangganya hancur (bercerai) karena hal tersebut dianggap akan mendatangkan aib.

Dalam pandangan (Rifa'i, 2007) awal mulanya praktek poligami hanya dilakukan oleh laki-laki Madura yang memiliki jabatan atau memiliki materi lebih, seperti tokoh agama, pejabat, atau seorang blater yang berpengaruh dalam lingkungan masyarakat. Namun praktik poligami yang terjadi belakangan ini dilakukan pula oleh laki-laki Madura yang tidak berkecukupan secara materi. Karena bagi sebagian masyarakat Madura menikah lebih dari satu kali atau berpoligami lebih baik daripada laki-laki tersebut berzinah. Faktor psikis perempuan Madura cenderung menerima keadaan tersebut sebagai takdir dan kodrat seorang perempuan untuk dimadu, menjadi salah satu kondisi yang mendukung praktek poligami di Madura terus berlangsung. Rumitnya prosedur pengurusan dan syarat-syarat pernikahan poligami secara resmi di KUA menjadi alasan bagi pelaku untuk melakukan pernikahan tersebut secara ilegal (siri), tanpa pencatatan resmi.

Dengan kondisi diatas, fenomena praktek poligami di Kamal Madura dapat diibaratkan seperti fenomena gunung es. Fakta di lapangan menunjukkan tidak terdapat data secara pasti berapa jumlah pelaku poligami. Hal ini disebabkan karena para pelaku poligami tidak tercatat dalam catatan pernikahan di Pengadilan Agama dan tidak terdaftar dalam catatan (status) kependudukannya. Pernikahan poligami dalam masyarakat tradisional Madura umumnya dilakukan secara siri. Kalaupun ada yang tercatat secara resmi, jumlahnya jauh lebih sedikit dibanding dengan yang siri.

Dalam fenomena poligami yang terjadi di Bangkalan perempuan menjadi pihak pertama yang dirugikan ketika dimadu. Hal ini dikarenakan kewajiban seorang istri dalam masyrakat Madura harus selalu tunduk, patuh, taat dan menyerah pada kekuasaan suami. Dalam pandangan Nugroho (Nugroho, 2008) bahkan perempuan (istri) tidak memiliki kekuatan untuk sekedar mengkomunikasikan ketidakinginannya dimadu. Perlakuan, aturan dan pemahaman yang bersifat tradisionalis masih membatasi perempuan Madura dalam bertindak, berbicara untuk menentukan nasibnya sendiri, tersirat bahwa peran perempuan hanya berfungsi sebagai peran pendukung semata.

Kondisi ini menjadi keunikan tersendiri dalam keluarga poligami di Madura, karena meskipun keadaan yang serba membatasi perempuan Madura karena kekuasaan masih berada penuh di tangan suami. Dengan kondisi seperti ini keluarga poligami Madura mampu bertahan bahkan dapat menjadi keluarga yang langgeng, kadang lebih 
dari keluarga monogami. Hal ini yang kemudian menjadi alasan pemilihan tema penelitian ini. Dengan kondisi demikian, bagaimanakah komunikasi perempuan dalam keluarga berpoligami di Madura?

Ada beberapa penelitian yang menjadi state of the art penelitian ini , diantaranya adalah Praktek Poligami Pada Masyarakat Madura Di Kelurahan Siantan Tengah Kecamatan Pontianak Utara Oleh Moh. Hosis (2017) . Dalam kajiannya, (Hosis, 2017) menjelaskan dalam masyarakat Madura masalah poligami bukan hal yang sulit untuk dilakukan dan dapat dikatakan sudah menjadi kebiasaan. Laki-laki dalam masyarakat Madura begitu mudah melakukan poligami karena mereka melakukan poligami secara di bawah tangan (siri), di mana proses perkawinan keduanya dilakukan tanpa dicatatkan pada kantor urusan agama (kua) sehingga tidak mendapatkan akta pernikahan yang sah dari kantor urusan agama (KUA). Selain itu, perkawinan poligami yang dilakukan oleh laki-laki dalam masyarakat Madura tanpa perlu meminta persetujuan dari isteri maupun izin dari pengadilan agama. Dalam kenyataannya, praktek poligami pada masyarakat madura di kelurahan siantan tengah kecamatan pontianak utara yang tidak sesuai dengan ketentuan undangundang nomor 1 tahun 1974 tentang perkawinan. Faktor penyebab terjadinya praktek poligami pada masyarakat Madura di kelurahan Siantan Tengah Kecamatan Pontianak Utara adalah karena poligami tidak dilarang dalam agama islam dan poligami merupakan haklaki-laki sertamereka tidak mengerti prosedurnya melakukan poligami.

Penelitian selanjutnya adalah "Poligami dalam media film Indonesia" dilakukan oleh Finy F.Basarah yang berusaha memaparkan masalah dan konflik yang terjadi dalam perkawinan poligami. Data yang diinterpretasikan dalam film dikaji melalui analisa wacana semiotika. Hasil analisis rangkaian tanda yang dianalisa oleh peneliti akan dapat menggambarkan konsep pemikiran yang akan disampaikan pembuat film tentang masalah poligami. (Basarah, 2006)

Penelitian tentang poligami berikutnya dilakukan oleh Hanafi Martadikusuma berjudul Stigma Poligami dan Kesetaraan Gender (Perspektif Islam dan Hukum Perkawinan Indonesia). Penelitian ini membahas masalah masalah poligami yang terjadi di tengah masyarakat Indonesia dengan kajian agam Islam dan hukum-hukumnya. Beragam penelitian diatas mendasari penelitian tentang bagaimana komunikasi perempuan dalam keluarga berpoligami di Bangkalan Madura.

Keluarga merupakan unit terkecil dalam kehidupan manusia. Manusia tumbuh dan berkembang umumnya diawali dari pengasuhan keluarga yang terdiri dari pengasuhan orang tua kepada anak. Keluarga juga merupakan investasi awal untuk membangun kehidupan sosial dan kehidupan bermasyarakat secara luas menjadi lebih baik, terutama berkaitan dengan penanaman nilai-nilai toleransi kepada anak sejak dini (bkkbn.go.id, 2016).

Keluarga adalah unit sosial terkecil yang memberikan fondasi primer bagi perkembangan anak. Sedang lingkungan sekitar dan sekolah ikut memberikan nuansa pada perkembangan anak. Karena itu baik buruknya struktur keluarga dan masyarakat sekitar memberikan pengaruh baik atau buruknya pertumbuhan kedisiplinan anak (Kartono, 1995)

Keluarga adalah sekumpulan orang yang hidup bersama dalam tempat tinggal bersama dan masing- masinganggota merasakan adanya pertautan batin sehingga terjadi saling mempengaruhi dan saling memperhatikan. (Schohib, 1998 : 17). Dalam konteks ini, komunikasi dalam keluarga merupakan salah satu bentuk komunikasi antar pribadi yang 
khas. Adapun ciri khas komunikasi antar pribadi yang membedakan dengan komunikasi massa adalah : (1) terjadi secara spontan, (2) tidak mempunyai struktur yang teratur atau diatur, (3) terjadi secara kebetulan, (4) tidak mengejar tujuan yang telah direncanakan terlebih dahulu, (5) dilakukan oleh orang-orang yang identitas keanggotaannya kadangkadang kurang jelas, (6) bisa terjadi sambil lalu (Liliweri, 1997)

\section{METODE}

Penelitian ini menggunakan paradigma konstruktivis dengan jenis penelitian kualitatif deskriptif. Menurut (Sugiarti, 2008) laporan hasil penelitian kualitatif deskriptif berisi kutipankutipan dari data sebagai ilustrasi dan untuk memberikan dukungan atas apa yang disajikan. Data meliputi trasnkrip wawancara, catatan lapangan, foto, rekaman, dokumen pribadi, memo dan catatan resmi lainnya. Data dianalisis dengan kekayaan maknanya sedekat mungkin dengan wujud rekaman atau transkripnya.

Pengumpulan data ini menggunakan wawancara mendalam (depth interviews) , observasi. Kedua teknik pengumpulan data ini digunakan untuk mendapatkan data di lapangan agar lebih akurat khususnya dalam penggalian data primer, karena melalui wawancara dan observasi peneliti dapat memperoleh data dalam setting yang alami (natural setting). Narasumber atau informan dalam penelitian ini adalah para perempuan atau istri dalam keluarga poligami, baik sebagai istri pertama maupun istri kedua. Selain para istri dalam keluarga poligami, narasumber lain adalah para suami pelaku poligami dan seorang kerabat dekat keluarga poligami. Dengan kriteria informan tersebut, data primer dalam penelitian diperoleh melalui wawancara mendalam dengan empat keluarga berpoligami, dengan rincian tujuh perempuan yang dipoligami, baik istri pertama maupun istri kedua, tiga orang laki-laki pelaku poligami dan seorang informan pendukung yaitu kerabat dalam keluarga berpoligami. Hasil wawancara dengan informan penelitian ini adalah data primer yang digunakan sebagai dasar analisa hasil penelitian, penentuan kategori penelitian, serta menentukan temuan atau keunikan dalam tema penelitian ini.

\section{TEMUAN DAN PEMBAHASAN}

Hasilpenelitian ini mendeskripsikan tentang temuan-temuan data di lapangan tentang komunikasi perempuan dalam keluarga poligami di Bangkalan Madura. Praktek poligami di wilayah Kamal Madura bukanlah hal baru, hal ini dibuktikan bahwa di tiap-tiap desa di wilayah ini ditemukan kasus poligami dengan beragam alasan dan latar belakang penyebabnya. Berdasarkan hasil observasi ditemukan data bahwa pernikahan poligami yang terjadi di wilayah Bangkalan ini memiliki latar belakang yang berbeda-beda. Perbedaan latar belakang ini juga menyebabkan perbedaan perilaku, sikap dan penerimaan perempuan yang mengalami praktek poligami

\section{Profil Keluarga Poligami}

Keluarga A adalah keluarga poligami dengan alasan kepercayaan. Pernikahan dengan istri pertama telah berlangsung 23 tahun, sampai suami memutuskan untuk menikah lagi. Keluarga poligami ini termasuk keluarga yang harmonis, karena pernikahan dengan istri kedua mendapat ijin dari istri pertama, dengan alasan bahwa dalam Islam menikah dengan lebih dari satu istri adalah sunnah. Keharmonisan keluarga ini bukan hanya dilihat dari kerelaan dan ijin dari istri pertama bagi suami untuk menikah lagi, namun juga terlihat secara ekonomi. Kondisi ekonomi kedua istri 
tercukupi, masing-masing istri memiliki rumah sendiri, dan anak-anak dari istri pertama mendapatkan pendidikan yang tinggi .

Keluaga B adalah keluarga poligami dengan tipikal hampir sama dengan keluarga A. Setelah 24 tahun pernikahan pertama tidak dikaruniai anak, maka suami memutuskan menikah lagi untuk mendapatkan keturunan. Keluarga B termasuk kategori keluarga poligami yang harmonis karena secara ekonomi berkecukupan dan kedua istri hidup rukun. Kedua istri meskipun tinggal di rumah yang berbeda, namun mereka saling mengunjungi dan mengasuh anak istri kedua secara bergantian.

Keluarga $\mathrm{C}$ adalah keluarga poligami dengan latar belakang berbeda dari dua keluarga sebelumnya. Suami dalam keluarga $\mathrm{C}$ ini melakukan pernikahan poligami tanpa sepengetahuan dan tanpa ijin istri pertama. Pada kasus keluarga $\mathrm{C}$ ini, kedua istri merasa samasama tertipu oleh suami mereka. Istri pertama tertipu karena tidak mengetahui kalau suami menjalin hubungan sampai menikah dengan istri kedua. Sedangkan istri pertama merasa tertipu karena sejak awal perkenalan suami mengaku masih bujang. Dengan latar belakang seperti ini, dalam keluarga $\mathrm{C}$ sering terjadi konflik rumah tangga yang melibatkan suami dan kedua istri. Perlakuan tidak adil dianggap sebagai salah satu pemicunya. Hal ini juga diperparah dengan kondisi ekonomi keluarga yang tidak mencukupi. Keluarga C memiliki tiga orang anak, dua orang dari istri pertama dan satu anak dari istri kedua.

Keluarga D adalah keluarga poligami dengan latar belakang yang agak rumit dan kompleks. Suami dalam keluarga D ini pada awalnya memiliki empat orang istri. Dari pernikahannya dengan tiga istri tersebut, suami belum memperoleh keturunan. Dengan alasan ini, suami memutuskan menikah untuk keempat kalinya. Hampir sama dengan keluarga $\mathrm{C}$, istri keempat ini tidak mengetahui kalau suami sudah memiliki tiga orang istri. Setelah beberapa belan menikah dan istri keempat hamil, si istri baru mengetahui kalau suami sudah beristri tiga. Dengan kondisi ini, suami akhirnya menceraikan dua istri sebelumnya, yaitu istri kedua dan ketiga. Dibanding dengan tiga pasangan poligami sebelumnya, keluarga ini merupakan keluarga yang paling berlimpah secara materi. Masing-masing istri memiliki rumah dan kendaraan mobil serta kondisi perekomomian serba berlimpah.

\section{Kondisi Perempuan dalam Keluarga Poligami}

Perempuan dalamkeluarga poligami di Madura dikategorikan menjadi dua kelompok, yaitu yang secara sadar mau dipoligami, dan yang kedua perempuan yang "tertipu" sehingga mau dipoligami. Perempuan yang masuk dalam kategori pertama biasanya adalah istri pertama yang mau melakukan poligami karena alasan kepercayaan dan tidak memiliki anak. Mereka berpandangan bahwa Islam membolehkan laki-laki menikah dengan lebih dari satu istri. Alasan ini umumnya menguat pada istri pertama bila mereka tidak memiliki anak, sehingga mengijinkan suami menikah lagi. Bagi istri pertama tipe ini, tidak ada solusi lain selain poligami. Dengan poligami suami mendapatkan keturunan, dia juga masih memiliki status istri, sehingga terhindar dari stigma "aib" karena perceraian.

Sedangkan yang masuk dalam kategori kedua biasanya adalah istri kedua. Istri kedua pada keluarga poligami dalam penelitian ini biasanya tidak mengetahui status suaminya sudah menikah, bahkan dengan beberapa istri. Meskipun ada dua orang yang secara sadar bersedia menjadi istri kedua karena alasan kenyamanan ekonomi. Hubungan antara istri pertama dan kedua dalam pernikahan poligami 
biasanya rawan konflik karena faktor kecemburuan.

\section{Komunikasi Perempuan dalam Keluarga Poligami}

Komunikasi perempuan dalam keluarga poligami pada penelitian ini terbagi menjadi beberapa kategori, diantaranya adalah komunikasi antara istri pertama dengan istri kedua, istri pertama dengan suami, istri kedua dengan suami, serta antara istri pertama dengan istri kedua. Kategori ini untuk membandingkan jenis komunikasi, pesan baik verbal maupun non verbal, maupun konflik yang muncul dalam interaksi keluarga poligami.

Dominasi istri pertama terhadap istri kedua terlihat dalam komunikasi keluarga berpoligami. Dominasi ini ditunjukkan dalam interaksi dengan suami maupun istri keduanya dalam beragam urusan. Masalah pembagian waktu kunjung, jatah keuangan dan beberapa keperluan lain sering membuat istri pertama sangat dominan dalam pengambilan keputusan. Hal ini seolah menunjukkan bahwa keikhlasannya untuk dimadu harus diikuti oleh kerelaan suami untuk mengutamakan dia dibanding istri keduanya. Istri pertama cenderung memegang kendali dalam beberapa keputusan keluarga.

Sikap dominasi istri pertama dalam keluarga berpoligami ini bertolak belakang dengan sikap istri kedua yang cenderung pasrah. Kepasrahan istru kedua ini lebih karena perasaan tidak berdaya dengan kondisi yang dialaminya. Apa yang dirasakan oleh istri kedua ini lebih nampak apabila pernikahan keduanya tanpa sepengetahuan istri pertama. Hal ini menjadi salah satu pemicu konflik dalam rumah tangga keluarga berpoligami. Konflik yang terjadi bisa antara suami dengan istri pertama maupun antara istri istri pertama dan istri kedua.

Konflik yang muncul dalam keluarga poligami pada akhirnya kerap memunculkan sikap "white lies" atau berbohong demi kebaikan. Kecenderungan berbohong ini dilakukan oleh suami maupun istri. Suami cenderung menyembunyikan informasi yang dapat memicu konflik antara istri pertama dan kedua. Kebohongan yang dilakukan suami biasanya menyangkut masalah jatah kunjungan, uang belanja yang tidak sesuai dengan kondisi yang sebenarnya. Istri berbohong pada madunya tentang keberadaan suami. Hal ini berkaitan dengan jatah kunjungan, bila salah satu istri mendapat jatah diluar jadwal seharusnya, biasanya dia akan berbohong pada madunya dengan mengatakan tidak tahu keberadaan suami.

Dalam pernikahan poligami, ijin dari istri pertama merupakan kunci utama menghindari konflik. Dari hasil penelitian di lapangan, ditemukan fakta bahwa masalah ijin atau restu dari istri pertama merupakan sumber dari adanya konflik. Bila pernikahan suami dengan istri kedua diketahui dan direstui oleh istri pertama, konflik relatif dapat dihindari oleh keluargapoligami. Hal ini disebabkan istri pertama menyadari kondisi dirinya yang tidak dapat memberikan keturunan, sehingga mengijinkan suami menikah lagi. Dalam kasus istri pertama yang memberikan ijin disebabkan oleh pemahaman akan kepercayaan yang membolehkan suami untuk memiliki istri lebih dari satu.

\section{Komunikasi verbal non verbal perempuan dalam keluarga berpoligami}

Dalam melakukan komunikasi dengan suami, istri pertama menggunakan pesan-pesan verbal maupun non verbal. Pesan verbal mereka sampaikan dalam interaksi sehari-hari dalam kondisi yang normal, tanpa adanya konflik atau masalah yang timbul dalam keluarga. Pesan-pesan disampaikan melalui percakapan baik langsung maupun menggunakan media 
ponsel. Demikian juga dengan istri kedua menggunakan pesan verbal secara langsung melalui percakapan dan media ponsel.

Hal ini berbeda dengan saat terjadi konflik atau masalah diantara keluarga berpoligami. Apabila ada masalah, istri pertama lebih sering diam dalam interaksi dengan suami. Hal ini menunjukkan bahwa diam adalah pesan non verbal istri pertama dalam menunjukkan sikap tidak suka pada kondisi tertentu dalam keluarga. Biasanya masalah dipicu oleh rasa cemburu, merasa diperlakukan tidak adil, tidak diperhatikan, dicuekin dan pembagian jatah kunjungan maupun jatah keuangan. Hal hampir sama juga terjadi pada istri kedua yang merasa lebih sering diperlakukan secara tidak adil. Pesan non verbal yang sering ditunjukkan antara lain menangis, cemberut, bermuka masam, sedih. Hal ini dilakukan sebagai ungkapan kekecewaan, cemburu, tersakiti, tertipu dan perasaan tidak mengenakkan lainnya yang umumnya dialami oleh istri kedua.

Pesan yang kontradiktif dari istri pertama kepada istri kedua. Istri pertama akan mengatakan kebalikan dari kenyataan yang sesungguhnya. Istri pertama akan mengatakan kepada istri kedua bahwa suami nya sudah tua, tidak ganteng, dan dia tidak mencintainya . Hal ini sebenarnya dilakukan agar istri kedua maupun perempuan lain tidak suka pada suaminya.

\section{SIMPULAN}

Hasil penelitian ini mendeskripsikan tentang temuan-temuan data di lapangan tentang komunikasi perempuan dalam keluarga poligami di Bangkalan Madura. Perempuan dalam keluarga berpoligami dikategorikan menjadi dua yaitu yang secara sadar mau menerima untuk dipoligami, dan yang kedua perempuan yang "tertipu" sehingga mereka akhirnya pasrah untuk dipoligami. Perempuan yang secara sadar dipoligami karena kondisi pernikahan yang tidak dikaruniai anak, sehingga mengijinkan suami untuk menikah lagi. Alasan lain bagi perempuan yang sadar dipoligami adalah karena masalah kepercayaan, dan faktor ekonomi dan status sosial. Sedangkan perempuan yang "tertipu" dalam praktek poligami, karena sejak awal perkenalan suami mengaku sebagai bujang, dan baru mengetahuinya setelah beberapa bulan mereka menikah.

Istri pertama dalam keluarga berpoligami sangat dominan memegang kendali keluarga, utamanya masalah waktu kunjung, jatah keuangan dan keputusan-keputusan penting dalam keluarga. Sebaliknya istri kedua dalam keluarga berpoligami sering berada dalam posisi tersubordinasi oleh istri pertama. Komunikasi perempuan dalam keluarga berpoligami berupa pesan verbal dan non verbal. Pesan verbal berupa kalimat-kalimat percakapan maupun pesan melalui media ponsel. Sedangkan pesan non verbal istri berupa sikap diam yang umumnya dipicu oleh rasa cemburu, merasa diperlakukan tidak adil, tidak diperhatikan, dicuekin dan pembagian jatah kunjungan maupun jatah keuangan. Pesan kontradiktif juga menjadi ciri pesan yang disampaikan oleh istri pertama kepada istri kedua. Isi pesan yang disampaikan tidak sesuai dengan kondisi yang sebenarnya.

\section{DAFTAR PUSTAKA}

Basarah, F. F. (2006). Poligami Dalam Media Film Indonesia (Analisis Semiotika Roland Barthes Film "Berbagi Suami"). Universitas Padjadjaran Bandung. Pogram Pascasarjana Program Studi Ilmu Komunikasi.

Hosis, M. (2017, Vol5 No 2). Praktek Poligami Pada Masyarakat Madura Di Kelurahan Siantan Tengah Kecamatan Pontianak Utara. e journal Gloria Yuris Prodi Ilmu Hukum Untan. 
Nikmah Suryandari, dkk. Komunikasi Perempuan dalam Keluarga...

Kartono, K. (1995). Psikologi Remaja. Bandung: PT Mandar maju.

Liliweri, A. (1997). Komunikasi Antar Pribadi. Bandung: Citra Aditya Bakti.

Martadikusumah, H. (2010, January 6). Dipetik january 6, 2010, dari www. poligami dalam Islam.com.

Mernissi, F. (1997). Beyond the Veil. In F. Mernissi, Beyond the Veil (p. 47). Surabaya, Surabaya: ALFIKR.

Nugroho, R. (2008). Gender dan Strategi. Yogyakarta: Pilar Media.
Rahmawati, F. N. (2007). Representasi seksualitas perempuan Madura dalam orang Madura tak mati lagi. Jurnal Komunikasi Vol 1.

Rifa'i, M. A. (2007). Manusia Madura. In M. A. Rifa'i, Manusia Madura. Yogyakarta: Pilar Media.

Schohib, S. d. ((1998: 17)). Pola Asuh Orang tua . Jakarta: Rineka Cipta.

Sugiarti, T. h. (2008). Konsep dan Penelitian Gender. Malang: Universitas Muhammadiyah Malang. 